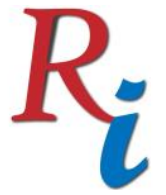

Asia Proceedings of Social Sciences

(APSS)

www.readersinsight.net/APSS

\title{
GENERATION Y EMPLOYEES IN THE BANKING SECTOR IN MALAYSIA: SOCIAL NEEDS, INTENTION TO STAY AND PERCEIVED ORGANIZATIONAL SUPPORT
}

\section{Zabedah bt Othman}

OUM Business School

Open University Malaysia

Malaysia

\section{Jugindar Singh Kartar Singh*}

School of Management

Asia Pacific University of Technology and Innovation University

Malaysia

\section{Raemah Abdullah Hashim}

OUM Business School

Open University Malaysia

Malaysia

*Corrosponding author's Email: jugidar.singh@gmail.com

Peer-review under responsibility of $3^{\text {rd }}$ Asia International Multidisciplanry Conference 2019 editorial board (http://www.utm.my/asia/our-team/) (c) 2019 Published by Readers Insight Publisher, lat 306 Savoy Residencia, Block 3 F11/1,44000 Islamabad. Pakistan, info@ readersinsight.net This is an open access article under the CC BY-NC-ND license (http://creativecommons.org/licenses/by-nc-nd/4.0/). 


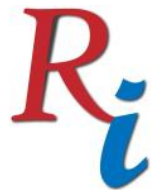

\section{Asia Proceedings of Social Sciences}

(APSS)

www.readersinsight.net/APSS

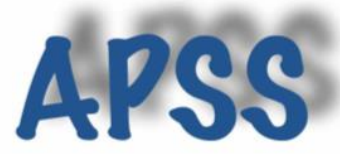

\section{Re se a r ch H i g h I i g h t s}

By year 2025, 75\% of the workforce will be Gen Y employees. This study examined the influence of social needs on the intention to stay by Gen Y employees in the banking sector in Malaysia. The mediation role of perceived organizational support between the two constructs was examined. In this quantitative study, primary data was collected from a sample of 470 respondents. The examination concluded that higher level of social needs had a positive and significant influence on intention to stay. This study further revealed that perceived organizational support partially mediated the relationship between social needs and intention to stay. Due to the expected rise of the Gen Y workforce in future, this study will give organizations a better understanding and knowledge of Gen Y social needs and provide them the right tools to collaborate and find the right solutions.

\section{Graphical A bstract}



\section{Research Objectives}

Employee turnover can be an indicator of stability and the cost of employee turnover can be high (Saridakis and Cooper, 2016). The direct costs of replacing an employee is around $\$ 7,000$ and this consists of the costs of hiring a new employee and the cost of training (Erickson, 2016). However, there is limited research on Gen Y intention to stay in the banking sector in Malaysia. In addition, the influence of Gen Y social needs towards intention to stay and the mediation effects of perceived organizational support has not empirically tested in the banking sector in Malaysia. Therefore, there is a need to examine social needs of Gen Y employees and the mediating role of perceived organizational support. This research could assist HR managers to understand the social needs of Gen $\mathrm{Y}$ and fine tune their strategies to encourage Gen $\mathrm{Y}$ employees to stay.

\section{Methodology}

This is an explanatory research that was used to examine the cause and effect relationship between the independent variables and the dependent variable (Sarstedt, and Mooi, 2019). This quantitative research design included procedures for collecting, analyzing, and reporting numeric data to answer research questions and test hypotheses. A cross-sectional study was undertaken where a sample of 470 respondents represented the population. The relationships 


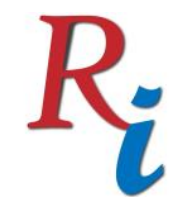

\title{
Asia Proceedings of Social Sciences
}

\author{
(APSS) \\ www.readersinsight.net/APSS
}

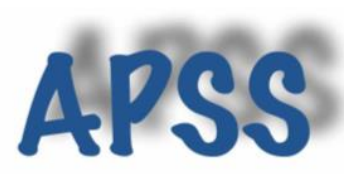

between variables was measured at one point in time using a survey design strategy (Clark and Creswell, 2010). This survey research design used quantitative procedures that were used by the researcher to administer survey questionnaires to collect data (Clark and Creswell, 2010). Probability sampling was used to create a sampling frame and identify the sampling elements. Self-administered questionnaires were used to collect numerical data from Gen Y employees in the banking sector. The SPSS and Smart-PLS were used to analyze the data and present the findings.

\section{Results}

The researcher distributed 500 questionnaires and 470 questionnaires or $94 \%$ were valid. A total of 230 respondents $(48.94 \%)$ were male and $240(51.96 \%)$ were female respondents. Majority of the respondents, $68 \%(\mathrm{n}=324)$ were single. In terms of working experience, $37 \%$ worked for at least 1 year, 23\% worked between 1 to 2 years and 23\% worked for more than 2 years. Convergent validity was confirmed because the average variance extracted (AVE) was higher than 0.50 (Ringle et al., 2015). The R2 value for the endogenous variable in this study was moderate $(52 \%)$. The R2 for the mediating variable Perceived Organizational Support was low $(14 \%)$. For the relationship between social needs and intention to stay, the t-value was significant. The standardized regression value of .14 shows a positive relationship between social needs and intention to stay and the effect was significant $(\mathrm{p}<0.05)$. The significant paths suggested that all hypotheses were supported. In this study, bootstrapping was done without the interaction of a mediator. The results revealed that both direct paths were statistically significant. Based on the t-value of the indirect path, with a p-value that is significant, it can be concluded that POS mediates the relationship between social needs and intention to stay

\section{Findings}

The findings of this study supported the relationship between social needs and intention to stay $(\beta 1=.142, \mathrm{p}<0.001)$. Greater social needs of Gen Y employees will lead to increase in intention to stay longer. The results of this study are consistent with past studies that have revealed that social needs are important (Caringal-Go and Hechanova, 2018). In addition, this study revealed that POS mediates the relationship between social needs and intention to stay longer by Gen Y employees. This means social needs predict POS and POS in turn predicts Gen Y employees' intention to stay longer in the banking sector. The results of this study were similar to another study by Liu and Liu (2016).

\section{References}

Caringal-Go, J.F. and Hechanova, M.R.M. (2018) Motivational Needs and Intent to Stay of Social Enterprise Workers. Journal of Social Entrepreneurship, 9(3), pp200-214

Clark, V.L.P. and Creswell, J.W. (2010). Understanding research: A consumer's guide. Merrill/Pearson Educational.

Clark, V.L.P. and Creswell, J.W. (2010). Understanding research: A consumer's guide. Merrill/Pearson Educational.

Erickson, R. (2016). Calculating the True Cost of Voluntary Turnover: The Surprising ROI of Retention. Bersin by Deloitte. (Online) Retrieved from https://login.bersin.com/uploadedFiles/021517-calculating (Assessed January 6, 2019)

Liu, J. and Liu, Y.H. (2016). Perceived organizational support and intention to remain: The mediating roles of career success and self-esteem. Int. journal of nursing practice, 22(2), pp.205-214.

Saridakis, George and Cooper, Cary L., eds. (2016). Research handbook on employee turnover. Cheltenham, U.K.: Edward Elgar Publishing Limited

Sarstedt, M. and Mooi, E. (2019). Cluster analysis. In A concise guide to market research. Springer, Berlin, Heidelberg. 